\title{
CLINICAL AND MICROBIOLOGICAL SUBSTANTIATION OF TOPICAL APPLICATION OF SORPTION HYDROPHILIC/HYDROPHOBIC COMPOSITION BASED ON NANOSILICA IN THE TREATMENT OF PATIENTS WITH BURNS
}

\author{
${ }^{1}$ Chornopyshchuk R.M. https://orcid.org/0000-0001-5422-7495 \\ ${ }^{1}$ Nagaichuk V.I. https://orcid.org/0000-0001-9238-9276 \\ ${ }^{2}$ Gerashchenko I.I. https://orcid.org/0000-0001-8796-9137 \\ ${ }^{1}$ Nazarchuk O.A. https://orcid.org/0000-0001-7581-0938 \\ ${ }^{3}$ Sidorenkov S.A. https://orcid.org/orcid.org/0000-0003-0382-4542 \\ ${ }^{\text {I} C h e p l i a k a ~ O . M . ~ h t t p s: / / o r c i d . o r g / 0000-0003-0116-3218 ~}$ \\ ${ }^{4}$ Sidorenko L.A. https://orcid.org/0000-0002-0971-2819 \\ ${ }^{1}$ National Pirogov Memorial Medical University, Vinnytsya, Ukraine \\ ${ }^{2}$ Chuiko Institute of Surface Chemistry, NAS of Ukraine, Kyiv, Ukraine \\ ${ }^{3}$ Rehabilitation Centre, Valens, Switzerland \\ ${ }^{4}$ State Medical and Pharmacentical University N. Testemitanu, Chisinau, Republic of Moldova \\ r.chornopyshchuk@gmail.com
}

Relevance.One of the promising methods of treatment of patients with burns is the local use of sorption agents with antimicrobial properties.

Objective: experimental study of antimicrobial properties and clinical evaluation of the effectiveness of local use of a new sorption composition based on nanosilica in the complex treatment of patients with burns.

Materials and methods. The suggested sorption nanocomposition included highly dispersed silicon dioxide, polymethylsiloxane, decamethoxine, metronidazole.

The experimental study involved the study of the antimicrobial properties of the sorption nanocomposition and antimicrobial agents which are part of it.

The clinical material consisted of the results of examination of 42 patients with IIab-III degree burns with an area of 10-30\% of the body surface. Depending on the tactics of local treatment, patients were divided into 2 groups: after early necrectomy, xenodermoplasty, the wound surface of the patients in the main group $(n=20)$ was treated with a solution of decamethoxine in combination with the same sorption powder. Treatment in the comparison group $(\mathrm{n}=22)$ was similar except the use of sorption drugs. The examination included visual inspection of the injured area in combination with microbiological monitoring of the wound contents on the 3rd,7th,14th day.

Results. The obtained results confirmed the sufficient antimicrobial potential of the studied sorption nanocomposition, the properties of which are not inferior to the existing antiseptics for museum and clinical strains of microorganisms and fungi.

Signs of a more favorable wound healing process of the patients in the main group were observed: faster wound cleaning, less inflammatory reactions and much shorter preparation of wounds for grafting.

Conclusions. The obtained results convincingly indicate the effectiveness of a multicomponent composite based on nanosilica with antimicrobial components in a comprehensive treatment of patients with burns.

Key words: burns, wound healing process, infection, antiseptics, sorbents.

Relevance. Despite significant progress in the development of new technologies for the treatment of patients with thermal injuries, many problems of medical assistance remain far from being solved [1, 2]. An important prerequisite for their improvement was the significant achievements of scientists all over the world in understanding some pathogenetic features of the processes initiated by traumatic burn agents. In particular, the occurrence of burns as a response of the body to severe burns resulting in irritation, damage and death of numerous skin receptors followed by changes in the vital functions of all internal organs, systems, as well as metabolic disorders [3, 4]. One of the main etiological elements of the process development is numerous specific and nonspecific toxins, includ- ing those of microbial origin, which come from areas of necrotic tissue $[5,6]$. Hence, the local use of sorption agents in combination with antimicrobial substances is an important element of comprehensive treatment. Such agents include sorption hydrophilic/hydrophobic nanocomposition based on silica with the addition of antimicrobial drugs decamethoxine and metronidazole, information on the use of which in patients with burns is almost absent in the available literature.

The objective of this research was an experimental study of antimicrobial properties and clinical evaluation of the effectiveness of local use of a new sorption composition based on nanosilica in the complex treatment of patients with burns. 


\section{MATERIALS AND METHODS}

The suggested sorption agent included hydrophilic highly dispersed silicon dioxide, hydrophobic polymethylsiloxane, a two quaternary ammonium compound decamethoxine, a synthetic (5-nitroimidazole derivative) antiprotozoal antibacterial agent - metronidazole - in an appropriate proportion of masses without violating the limits of their safe therapeutic concentrations. The composition was prepared according to the original method, which involves mechanochemical immobilization of decamethoxin on the polymethylsiloxane surface and metronidazole on the silicon dioxide surface respectively. Subsequently, the obtained intermediates were mixed with highly dispersed silicon dioxide in a certain proportion. The ratio between the hydrophilic and hydrophobic component can be changed depending on the severity of the exudative process in the wound. The composition content and manufacturing method are protected by the corresponding patents (USA Patent US 10,226,425 B2).

Microbiological screening of the antimicrobial efficacy in vitro of the suggested hydrophilic hydrophobic composite and antimicrobial agents decamethoxine, metronidazole, which are part of it as a comparison, was performed prior to the clinical study. Museum test strains of gram-positive microorganisms Staphylococcus aureus ATCC 25923, gram-negative representatives of Escherichia coli ATCC 25922, Pseudomonas aeruginosa ATCC 27853, Proteus vulgaris ATCC 4636 were used for the study. Additionally, clinical isolates of pathogens of purulent inflammatory complications Staphylococcus aureus (n $=35)$, Escherichia coli $(\mathrm{n}=26)$, Pseudomonas aeruginosa $(\mathrm{n}=20)$, Candida albicans $(\mathrm{n}=16)$, Proteus vulgaris $(\mathrm{n}$ $=10)$, Bacteroides fragilis $(\mathrm{n}=8)$, Peptostreptococcus anaerobius $(\mathrm{n}=8)$, Bacillus subtilis $(\mathrm{n}=7)$ were studied. All the cultures of clinical strains of microorganisms were endowed with typical species, morphological, tinctorial, cultural and biochemical properties. The antimicrobial properties of composite and antimicrobial comparison agents were investigated using a standard agar diffusion method. To approximate the conditions for studying the antimicrobial activity of antimicrobial agents to the conditions of the wound surface, nutrient media were inoculated with suspension of daily cultures of microorganisms in the amount of $1 \times 10^{8} \mathrm{CFU} / \mathrm{ml}$. Evaluation of antimicrobial activity was determined by growth retardation zone around the wells $(\mathrm{mm}) 24$ hours after culturing microorganisms $\left(\mathrm{t}=37^{\circ} \mathrm{C}\right)$. Cultivation of microorganisms Bacteroides fragilis, Peptostreptococcus anaerobius, Bacillus subtilis was performed under anaerobic conditions $[7,8]$.

Evaluation of the results of microbiological research by agar diffusion method was performed according to the degree of growth retardation in the area of application of researched composition. The following criteria were used: absence of growth retardation zones of microorganisms around the well, a delay of up to $10 \mathrm{~mm}$ indicated the lack of sensitivity of the microorganism to the tested drug; the growth retardation zone with a diameter of 10 $15 \mathrm{~mm}$ indicated a low sensitivity of the culture to the studied concentration of antibacterial substance; growth retardation zone with a diameter of $15-25 \mathrm{~mm}$ was regarded as an indicator of sensitivity of the microorganism to the studied drug substance; growth retardation zone of more than $25 \mathrm{~mm}$ testified to high sensitivity of the microorganism to the studied drugs.

The clinical material consisted of the results of examination of 42 patients with IIab-III degree flame burns, injury area $10-30 \%$ of the body surface, who were treated at the Clinical Center for Thermal Injury and Plastic Surgery of the Municipal Non-profit Enterprise «Vinnytsya Regional Clinical Hospital Vinnytsya Regional Council» in 2018-2020. All patients underwent complex infusion-transfusion, antibacterial, symptomatic treatment, dressing changes with antimicrobials, wound dressings, which were combined with active surgical tactics: early removal of necrotic tissues on the 2 nd - 3rd day after the injury, temporary closure of postoperative wounds with application of xenodermoplasty (LLC «Institute of Biomedical Technologies», Ternopil, Ukraine) and further restoration of skin integrity with free perforated autodermografts. Depending on the tactics of local drug treatment, patients were divided into 2 groups: the wound surface of the patients in the main group $(n=20$; average age $48.11 \pm 13.92$ years) after early necrectomy, xenodermoplasty while preparing wounds for skin grafting was treated by $0.02 \%$ solution of decamethoxine, evenly applied sorption powder and covered with a gauze bandage, impregnated with the same antiseptic. Local treatment of patients in the comparison group $(n=22$; average age $48.74 \pm 14.29$ years) was similar except the use of sorption drugs.

Control over the wound process course involved visual inspection of the injured area with microbiological identification of the pathogen and its semiquantitative analysis on the 3rd, 7th, 14th day from the moment of injury to treatment with antiseptic in compliance with the rules of asepsis. The wounds were cleaned of purulent necrotic secretions with a sterile gauze napkin. The material was taken with a cotton swab and then transported in a sterile test tube with Amies medium to a bacteriological laboratory for 2 hours. Inoculation on a nutrient medium and evaluation of the results were performed according to the original method developed on the Department of Microbiology of the Shupyk National Medical Academy of Postgraduate Education [9]. The results were identified by a set of morphological, cultural and biochemical characteristics.

Collection of material for the study was performed in compliance with patient safety rules, preserved rights and canons of human dignity, moral and ethical standards in accordance with the basic provisions of GSP (1996), The Convention on Human Rights and Biomedicine (from 
04.04.1997), The Helsinki Declaration of the World Medical Association on the ethical principles for scientific medical research involving human subjects (1964-2000), the Order of the Ministry of Health of Ukraine № 281 of 01.11.2000, the Code of Scientific Ethics of Ukraine (2009) and the mandatory consent of patients to participate in the research.

The obtained results were processed statistically using data processing software Microsoft Excel 2016 and «Statistica 5.5» (licence № AXXR910A374605FA).

\section{RESULTS AND DISCUSSION}

As a result of the evaluation of the growth retardation zones obtained in the study, the highest antimicrobial activity of the decamethoxine comparison preparation against all studied reference strains of microorganisms was established. Growth retardation zones around the wells with the studied sorption drug showed a similar high activity of the decamethoxine containing agent, which was similar in activity to decamethoxine against reference strains of Proteus vulgaris ATCC 4636 (14.35 \pm $0.31 \mathrm{~mm})$ and anaerobic bacteria Bacillus subtilis $(19,21$ $\pm 0,46 \mathrm{~mm})$. There was no difference in the antipseudomonal activity of the sorption nanocomposition and decamethoxine as evidenced by clear zones of growth retardation of Pseudomonas aeruginosa ATCC 27853, which were within $15 \mathrm{~mm}$ in diameter. The antistaphylococcal activity of metronidazole in combination with decamethoxine in the nanocomposite with sorption properties was slightly lower but provided a sufficient antimicrobial effect (diameter of the growth retardation zone amounted to $19.86 \pm 0.43 \mathrm{~mm}$ ). A similar pattern was observed in relation to Escherichia coli culture, where the suggested complex sorption agent delayed growth within $16.29 \pm$ $0.35 \mathrm{~mm}$, inferior to the solution of decamethoxine with a growth retardation zone of $23.42 \pm 0.31 \mathrm{~mm}$. In this case, the antimicrobial activity of the sorbent significantly exceeded the effect of metronidazole on museum strains of the studied gram-positive and gram-negative bacteria (Fig. 1).

High antimicrobial properties of the investigated sorption drug in relation to all investigated isolates of gram-positive and gram-negative pathogens of purulent inflammatory processes were also established. Its highest antimicrobial action was found against Staphylococcus aureus, where the diameter of the growth retardation zone was up to $19.37 \pm 0.24 \mathrm{~mm}$, moderately inferior to the antiseptic decamethoxine $(27.37 \pm 0.23 \mathrm{~mm})$. In general, the results of comparative activity of these drugs showed the same effective antimicrobial effect on clinical strains of gram-negative opportunistic pathogens Acinetobacter baumannii, Pseudomonas aeruginosa, Proteus vulgaris (diameters of growth retardation zones for the composite drug of the corresponding name was 17,68 $\pm 0,45 \mathrm{~mm}, 14,50 \pm 0,29 \mathrm{~mm}, 13,20 \pm 0,25 \mathrm{~mm}$ versus $17,29 \pm 0,41 \mathrm{~mm}, 14,55 \pm 0,11 \mathrm{~mm}, 14,60 \pm 0,31 \mathrm{~mm}$ for decamethoxine, respectively). In all these cases, the results of antimicrobial activity of the test composition did not differ significantly from that for the antiseptic solution of the corresponding name $(p>0.05)$. Less pronounced effect of the studied complex sorption drug and decamethoxine was found to Pseudomonas aeruginosa $(14,50 \pm 0,29 \mathrm{~mm}$ and 14,55 $\pm 0,11 \mathrm{~mm}$, respectively) and Proteus vulgaris $(13,20 \pm 0,25 \mathrm{~mm}$ and 14,60 \pm 0.31 $\mathrm{mm}$, respectively) where significant differences were also not found $(\mathrm{p}>0.05)$.

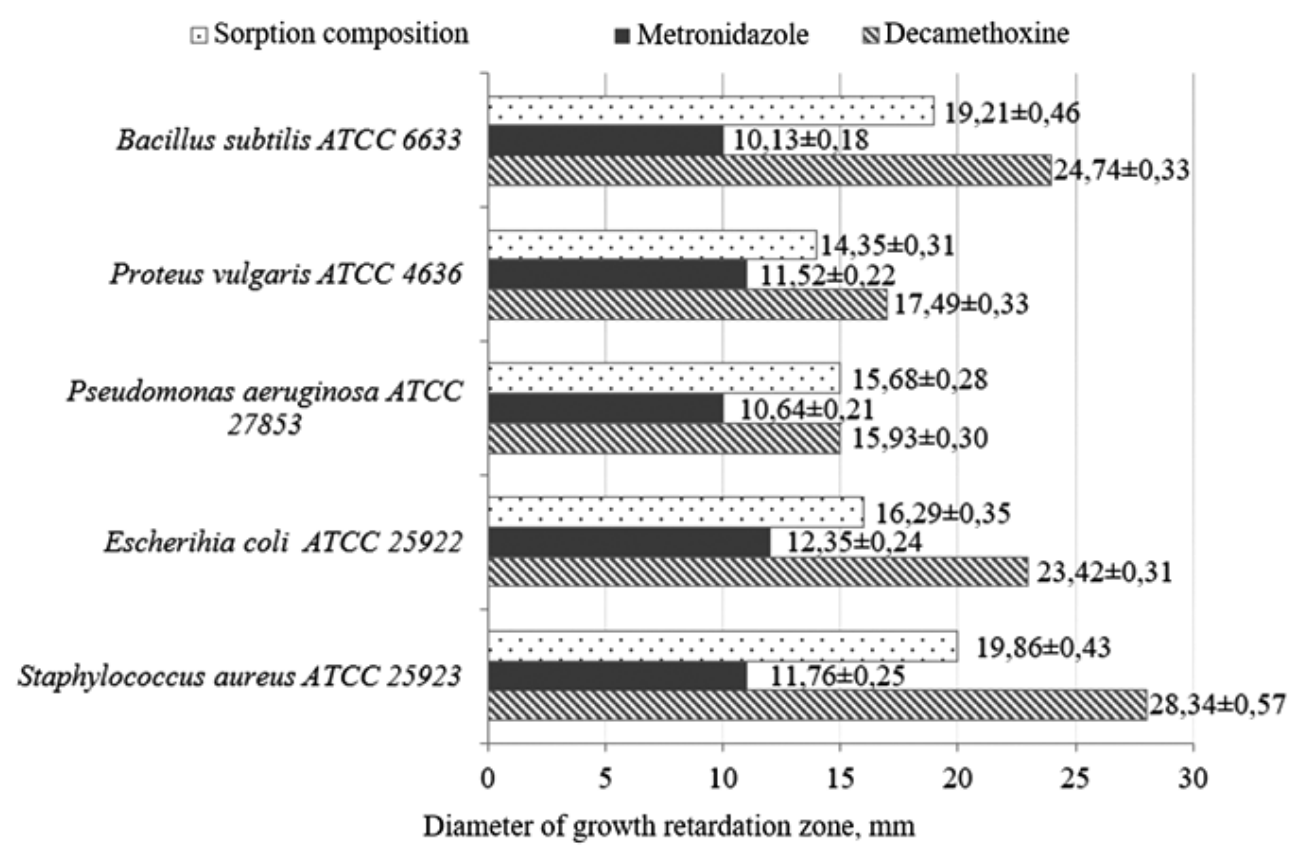

Fig. 1. The characteristics of antimicrobial activity of the tested drugs against museum strains of microorganisms by the results of agar diffusion method $(n=6)$ 
With regard to anaerobic opportunistic pathogens, all studied samples presented high antimicrobial activity without a significant difference concerning Peptostreptococcus anaerobius and Bacillus fragilis $(\mathrm{p}>0.05)$. Moreover, significant antibacterial properties of the suggested sorption drug and decamethoxine were established, which delayed the growth of Bacillus subtilis in the amount of 18,14 $\pm 0,34 \mathrm{~mm}$ and $22,86 \pm 0,51 \mathrm{~mm}$, significantly exceeding the indicators of metronidazole $(10,29 \pm 0,18 \mathrm{~mm})$.

The antifungal properties of composite, moderately inferior to the antimicrobial action of decamethoxine concerning Candida albicans, were at a sufficiently high level and statistically significantly exceeded the fungal activity of metronidazole almost in half $(\mathrm{p} \leq 0.01)$ (table 1$)$.

Objective examination of the wound surface in the period after radical necrectomy and xenodermoplasty during dressing changes with local use of antimicrobial drugs determined the remains of necrotic tissues, wound secretions, the amount of which decreased in dynamics with the subsequent formation of granulation tissue. At the same time, in patients of the study group, whose lo- cal treatment involved the use of sorption nanocomposition, the processes of wound cleaning from pathological layers proceeded much faster with less manifestations of inflammatory reaction both in the area of injury and in surrounding tissues. This, in turn, contributed to faster preparation of wounds for closure with skin grafts in comparison with patients whose treatment only included topical use of antiseptic solution of decamethoxine (table 2). Moreover, the effectiveness of surgical closure of postoperative wounds in patients of the main group was significantly higher with a larger area of engraftment of transplanted skin grafts.

According to the results of microbiological examination of the wound surface on the $3^{\text {rd }}$ day of observation, a similar microbial landscape was established, which was mainly represented by associations of microorganisms dominated by Staphylococcus aureus, Acinetobacter baumannii, Pseudomonas aeruginosa, the number of which in the wound content was expressed in decimal logarithms and amounted to $\lg (6,3 \pm 0,5) \mathrm{CFU} / \mathrm{ml}$ and $\lg (6,6 \pm 0,2) \mathrm{CFU} / \mathrm{ml}$ in the main group and the comparison group, respectively. As a result of additional use of

Table 1

Antimicrobial activity of the tested drugs against clinical strains of microorganisms by agar diffusion method

\begin{tabular}{|c|c|c|c|c|}
\hline \multirow[b]{2}{*}{ Microbial cultures } & \multirow{2}{*}{$\begin{array}{l}\text { Number of } \\
\text { clinical strains }\end{array}$} & \multicolumn{3}{|c|}{ Diameter of growth retardation zone, $\mathrm{mm}$} \\
\hline & & $\begin{array}{c}\text { Sorption } \\
\text { composition }\end{array}$ & Decamethoxin & Metronidazole \\
\hline Staphylococcus aureus & 35 & $19,37 \pm 0,24^{* x}$ & $27,37 \pm 0,23$ & $10,29 \pm 0,10$ \\
\hline Escherihia coli & 26 & $17,00 \pm 0,21 *$ & $21,85 \pm 0,15$ & $10,19 \pm 0,12$ \\
\hline Acinetobacter baumannii & 23 & $17,68 \pm 0,45^{\times}$ & $17,29 \pm 0,41$ & $10,61 \pm 0,17$ \\
\hline Pseudomonas aeruginosa & 20 & $14,50 \pm 0,29^{\times}$ & $14,55 \pm 0,11$ & $10,20 \pm 0,16$ \\
\hline Proteus vulgaris & 10 & $13,20 \pm 0,25^{\times}$ & $14,60 \pm 0,31$ & $10,00 \pm 0,15$ \\
\hline Peptostreptococcus anaerobius & 8 & $19,75 \pm 0,59$ & $20,50 \pm 0,50$ & $22,25 \pm 0,75$ \\
\hline Bacillus fragilis & 8 & $19,63 \pm 0,38$ & $20,00 \pm 0,57$ & $22,00 \pm 0,57$ \\
\hline Bacillus subtilis & 7 & $18,14 \pm 0,34^{* \times}$ & $22,86 \pm 0,51$ & $10,29 \pm 0,18$ \\
\hline Candida albicans & 16 & $19,38 \pm 0,30^{* x}$ & $25,38 \pm 0,30$ & $10,19 \pm 0,25$ \\
\hline
\end{tabular}

Note: $*$ - reliable difference $(p \leq 0.05)$ between this indicator and the indicator determined for decamethoxine;

${ }^{\times}$- reliable difference $(p \leq 0.01)$ between this indicator and the indicator determined for metronidazole

Clinical criteria for wound process course in the studied patients

\begin{tabular}{|c|c|c|}
\hline \multirow{2}{*}{ Clinical criteria, day } & \multicolumn{2}{|c|}{ Group of patients } \\
\cline { 2 - 3 } & Main group & Comparison group \\
\hline Normalization of body temperature & $5,9 \pm 0,19^{*}$ & $10,4 \pm 0,21$ \\
\hline Subjective reduction of pain intensity & $7,7 \pm 0,25^{*}$ & $12,7 \pm 0,23$ \\
\hline Cleaning the wound from pathological layers & $8,3 \pm 0,19^{*}$ & $11,5 \pm 0,14$ \\
\hline Appearance of granulation tissue & $4,8 \pm 0,21^{*}$ & $7,2 \pm 0,27$ \\
\hline Performing primary skin grafting & $9,7 \pm 0,18^{*}$ & $13,5 \pm 0,21$ \\
\hline Wound healing & $31,9 \pm 0,62^{*}$ & $37,3 \pm 0,58$ \\
\hline
\end{tabular}

Note: $*$ - reliable difference between the indicators in the studied groups $(p \leq 0.01)$ 
sorption materials, an effective decrease in the value of total microbial count in the wound was found but without statistical reliability. Thus, up to 14 days the quantitative content of microorganisms on the wound surface did not exceed $\lg (3,8 \pm 0,3) \mathrm{CFU} / \mathrm{ml}$, while in the comparison group this rate was $\lg (4,3 \pm 0,6) \mathrm{CFU} / \mathrm{ml}(\mathrm{p}>0.05)$.

For instance, patient $\mathrm{Z}$. of the main group, at the age of 51, received an inpatient card № 3262 in the burn department of the Clinical Center for Thermal Injury and Plastic Surgery of the non-profit utility enterprise «Vinnytsia Regional Pirogov Clinical Hospital of Vinnytsia Regional Council» on March 23, 2018 at 13:45 with the diagnosis «Burn disease, stage of severe burn shock. Flame burn of the IIab-III degree, $30 \%$ of lower extremities». Case history indicated that he was injured by flames at home about 12 hours before admittance due to careless use of flammable fuel substances near an open fire. First pre-hospital aid was provided immediately applying moistened napkins to visible burnt areas. Within 1 hour he was taken to the non-profit utility enterprise «Teplyk Central Regional Hospital» of Teplyk District Council by ambulance where the neutralization of the thermal agent was continued, central venous access was established, infusion therapy was started, and necrotomy was performed.

On the $3^{\text {rd }}$ day after the injury, an electric anaemic necrectomy was performed on the entire surface of the burn injury with the closure of postoperative wound surface with lyophilized xenodermografts. Subsequently, dressing changes were performed daily with the application of an antiseptic $0.02 \%$ solution of decamethoxine, application of the sorption nanocomposition and closure of the wound area with a gauze bandage impregnated with the antiseptic of the corresponding name (Fig. 2).
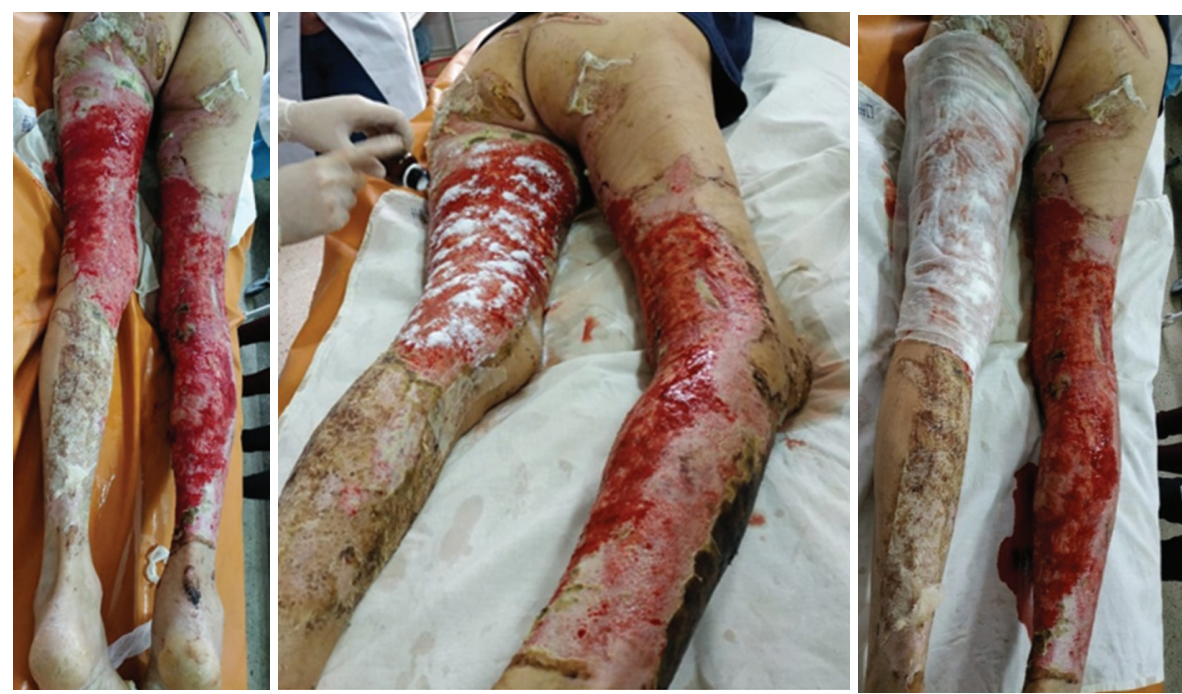

Fig. 2. Patient Z., 51 years old, inpatient card № 3262, 7th day after the injury. The wound is treated with a $0.02 \%$ solution of decamethoxine (a), the nanocomposition sorption agent (b) application of a gauze napkin impregnated with the antiseptic of the corresponding name (c)

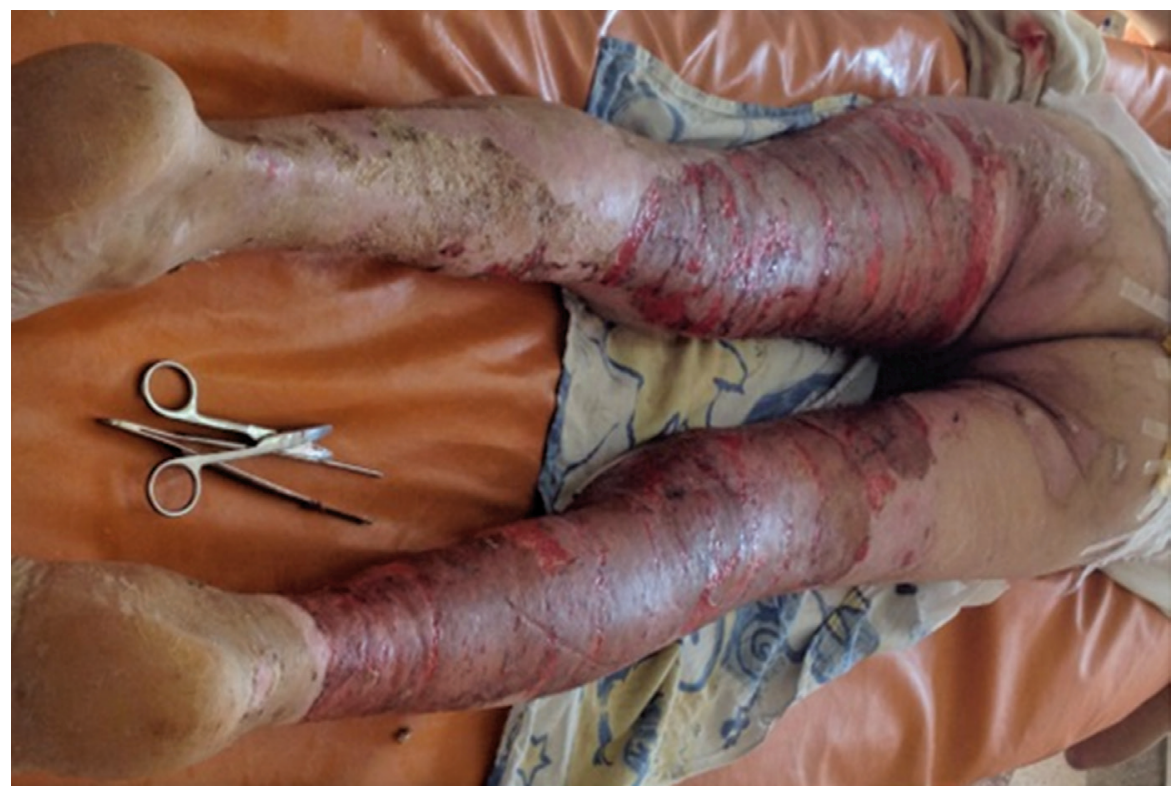

Fig. 3. Patient Z., 51 years old, inpatient card № 3262, before home discharge, $27^{\text {th }}$ day 
On the 10th day after the injury the wounds were filled with granulation tissue without necrotic tissues and pathological secretions, which made it possible to perform their surgical closure with skin grafts. 27 days after the injury the wounds healed with a complete skin grafts engraftment. The patient was discharged under supervision of doctors to the place of residence (Fig. 3).

A similar nature of injuries occurred in patient $\mathrm{K}$. from the comparison group, 41 years old, inpatient card № 22863, who was hospitalized at the Clinical Center on November 21, 2019, 16 hours after the injury. Diagnosis: «Burn disease, stage of severe burn shock. Burns of the IIab-III degree, $28 \%$ of lower extremities».

The traumatic mechanism and the amount of care provided were similar. After early necrectomy and xenoplasty on the 3rd day dressing changes were performed with antiseptic $0.02 \%$ decamethoxine solution. Unlike the previous patient, the process of cleaning wounds from necrotic tissues and pathological contents took much longer. Granulation tissue, color and structure of which differed qualitatively from that of the patients in the main group, formed more slowly, signs of inflammation persisted for a long time. Due to this, surgical closure of the wounds became possible only on the 15th day after the injury.

Subsequently, the patient underwent additional gradual skin grafting and healing occurred only 35 days later.

The search for effective treatment of burns has continued for many years [10]. Since the ancient times, means for local application, which still remain an important component of a comprehensive program of health care for patients with similar injuries, are mentioned as available materials. One of the first documented memoirs of treating patients with burn injuries can be found in Egyptian papyri dating back to $1600 \mathrm{BC}$, which contain information on balms based on natural resins, honey and other similar means [11]. Subsequent historical references tended to the empirical choice of means of natural origin, which mainly depended on ethnic and territorial features. A significant impetus in the formation of new approaches occurred during the XVIII-XIX centuries, when there was rapid scientific progress in understanding the peculiarities of the wound process in burns [12]. The initial goal in topical treatment was to «dry» the wound to create a protective layer of dry necrosis and reduce the permeability of toxins to the vascular bed. Thus, numerous sprays and ointments appeared, the choice of which depended on the condition of the wounds and the stage of the wound process [13]. Hydrophilic ointments based on polyethylene glycole of different molecular mass became especially widespread in the XX century, which allowed to combine several active agents at the same time, deliberately giving them the necessary properties regulating the direction and intensity of diffusion.

At the same time, the direction of efferent therapy appears and actively develops - various sorbents, which differ in chemical nature, method of their production: activated charcoal, ion-exchange resins, silicon, polymeric materials [14]. Radical change in the treatment strategy for patients with burn injuries (early active surgical tactics, use of «wet chamber» principles, etc.) helped to reconsider the feasibility of using certain groups of drugs, the necessity to find new and improve existing ones. Thus, a number of drugs with adsorption action appeared capable of keeping adsorbed substances on the verge between liquid and solid phases. Scientists developed a new composite drug based on highly dispersed silicon dioxide with immobilized antimicrobial substances on its surface - antiseptics, antibiotics capable of prolonged diffusion into the wound. The original nanocomposition sorption agent with antimicrobial properties on the basis of nanosilica, which is successfully used for application in purulent inflammatory diseases of different localization, has gained wide popularity [15].

The results of microbiological study of antimicrobial properties in «in vitro» experiments have established the ability of the drug to act on various pathogenic microorganisms, inhibiting the development of even anaerobic forms. A significant advantage of the drug is the ability to adversely affect the biofilm-forming properties of microorganisms, which was found in the example of clinical strains of Staphylococcus aureus 8 and Pseudomonas aeruginosa 24 even after 48 hours of observation.

Known sorption and confirmed high antimicrobial figures of sorption hydrophilic/hydrophobic composition indicate the prospects of its use in patients with burn injuries, which became the ground for its clinical use in the local treatment of wounds after necrotomy in preparation for skin grafting. The obtained results allowed to clearly establish the positive effect of composition on the processes of wound cleaning from necrotic tissues, excessive pathological secretions, reduction of microbial contamination, signs of inflammatory reaction, while contributing to the formation of granulation tissue. In general, this allowed to improve the condition of patients, the results of skin grafting, the rate of epithelialization of wound defects and significantly reduce the duration of inpatient treatment.

\section{CONCLUSIONS}

The results of studies «in vitro» convincingly indicate high antimicrobial activity of sorption hydrophilic/ hydrophobic composition based on nanosilica, polymethylsiloxane, decamethoxine, metronidazole. Proven antimicrobial ability of the drug to anaerobic flora is a special value of this drug.

Clinical efficacy of topical use of this sorption composition with an antiseptic solution of decamethoxine is confirmed by the results of rapid preparation of postoperative burn injuries for skin grafting with a high level of engraftment and a significant reduction in the length of bed rest. 
Acknowledgment. We express our gratitude to the administration of Vinnytsya National Pirogov Medical University headed by the rector, academician of the National Academy of Medical Sciences of Ukraine, professor Moroz V.M., director of Municipal Non-profit Enterprise «Vinnytsya Regional Clinical Hospital Vinnytsya Regional Council» Zhupanov O.B. in supporting and facilitating the study.

Conflict of interest. The authors declares that there is no conflict of interest.

\section{REFERENCES}

1. Rowan MP, Cancio LC, Elster EA, Burmeister DM, Rose LF, Natesan S, Chan RK, Christy RJ, Chung KK. Burn wound healing and treatment: review and advancements. Crit Care. 2015 Jun 12;19:243. DOI: 10.1186/s13054-015-0961-2.

View at: Publisher Site: http://ccforum.com/ content/19/1/243

PubMed: https://pubmed.ncbi.nlm.nih.gov/26067660/ PubMed Central: https://www.ncbi.nlm.nih.gov/pmc/ articles/PMC4464872/

2. Singh A, Bhatnagar A. Management of Superficial Partial Thickness Burn With Collagen Sheet Dressing Compared With Paraffin Gauze And Silver Sulfadiazine. Ann Burns Fire Disasters. 2020 Sep 30;33(3):233-8.

View at: PubMed: https://pubmed.ncbi.nlm.nih. gov/33304214/

PubMed Central: https://www.ncbi.nlm.nih.gov/pmc/ articles/PMC7680202/

3. Nagaichuk VI. [Modern approaches to assistance patients with burns]. State of art technology and medication. 2010;5(71):24-7. [in Ukrainian].

View at: URL: https://www.health-medix.com/articles/ misteztvo/2010-05-27/10VINHZO.pdf

4. Vigani A, Culler CA. Systemic and Local Management of Burn Wounds. Vet Clin North Am Small Anim Pract. 2017 Nov;47(6):1149-63. DOI: 10.1016/j. cvsm.2017.06.003.

View at: Scopus: https://www.sciencedirect.com/science/article/abs/pii/ S0195561617300645?via\%3Dihub

Publisher Site: https://www.vetsmall.theclinics.com/ article/S0195-5616(17)30064-5/abstract

PubMed: https://pubmed.ncbi.nlm.nih.gov/28802983/

5. Nielson CB, Duethman NC, Howard JM, Moncure M, Wood JG. Burns: Pathophysiology of Systemic Complications and Current Management. J Burn Care Res. 2017 Jan/Feb;38(1):e469-e481. DOI: 10.1097/ BCR.0000000000000355.

View at: Publisher Site: https://academic.oup.com/jbcr/ article/38/1/e469/4568966

PubMed: https://pubmed.ncbi.nlm.nih.gov/27183443/

PubMed Central: https://www.ncbi.nlm.nih.gov/pmc/ articles/PMC5214064/

6. Elmassry MM, Mudaliar NS, Colmer-Hamood JA, San
Francisco MJ, Griswold JA, Dissanaike S, Hamood AN. New markers for sepsis caused by Pseudomonas aeruginosa during burn infection. Metabolomics. 2020 Mar 13;16(3):40. DOI: 10.1007/s11306-020-01658-2. View at: Scopus: https://link.springer.com/ article/10.1007/s11306-020-01658-2

PubMed: https://pubmed.ncbi.nlm.nih.gov/32170472/ PubMed Central: https://www.ncbi.nlm.nih.gov/pmc/ articles/PMC7223005/

7. Jorgensen JH, Ferraro MJ. Antimicrobial susceptibility testing: a review of general principles and contemporary practices. Clin Infect Dis. 2009 Dec 1;49(11):174955. DOI: $10.1086 / 647952$.

View at: Publisher Site: https://academic.oup.com/cid/ article/49/11/1749/344384

PubMed: https://pubmed.ncbi.nlm.nih.gov/19857164/

8. Brook I, Wexler HM, Goldstein EJ. Antianaerobic antimicrobials: spectrum and susceptibility testing. Clin Microbiol Rev. 2013 Jul;26(3):526-46. DOI: 10.1128/ CMR.00086-12.

View at: Publisher Site: https://journals.asm.org/ doi/10.1128/CMR.00086-12

PubMed: https://pubmed.ncbi.nlm.nih.gov/23824372/ PubMed Central: https://www.ncbi.nlm.nih.gov/pmc/ articles/PMC3719496/

9. Shelkova N, Prokopets V. [Quantitative research method of maintenance of bacteria in clinical species which are selected by waddin tampon]. Collection of scientific works of staff member of P.L. Shupyk NMAPE. 2009;17(2):698-702. [in Ukrainian].

View at: URL: https://scholar.google.ru/ citations?user=z8jOGMAAAAAJ\&hl=uk

10. Hamblin MR. Novel pharmacotherapy for burn wounds: what are the advancements. Expert Opin Pharmacother. 2019 Feb;20(3):305-321. DOI: 10.1080/14656566.2018.1551880.

View at: Publisher Site: https://www.tandfonline.com/ doi/abs/10.1080/14656566.2018.1551880?journalCode $=$ ieop20

PubMed: https://pubmed.ncbi.nlm.nih.gov/30517046/ PubMed Central: https://www.ncbi.nlm.nih.gov/pmc/ articles/PMC6364296/

11. Artz CP. Historical aspects of burn management. Surg Clin North Am. 1970;50:1193-200. DOI: 10.1016/ s0039-6109(16)39279-9

View at: Scopus: https://www.sciencedirect.com/science/ article/abs/pii/S0039610916392799?via\%3Dihub PubMed: https://pubmed.ncbi.nlm.nih.gov/4922817/

12. Lee KC, Joory K, Moiemen NS. History of burns: The past, present and the future. Burns \& Trauma. 2014 Oct 25;2(4):169-80. DOI: 10.4103/2321-3868.143620. View at: Publisher Site: https://academic.oup.com/ burnstrauma/article/2/4/2321-3868.143620/5650557 PubMed: https://pubmed.ncbi.nlm.nih.gov/27574647/ PubMed Central: https://www.ncbi.nlm.nih.gov/pmc/ articles/PMC4978094/ 
13. Barillo DJ. Topical antimicrobials in burn wound care. A recent history of wounds. Wounds. 2008;20:192-8. View at: PubMed: https://pubmed.ncbi.nlm.nih. gov/25942608/

Europe PMC: https://europepmc.org/article/ $\mathrm{med} / 25942608$

14. Chernyakova GM, Minukhin VV, Voronin EP, Minukhin DV, Krasnoyaruzskyi AG, Efimov DS, Ponomaryova KV. [Substantiation for antimicrobial efficacy of applicational bionanocomposits in the treatment of the burn infection, caused by S.aureus and P.aeruginosa]. Klinicheskaia khirurgiia. 2017;12:48-51. [in Ukrainian]. DOI: 10.26779/2522-1396.2017.12.48

View at: Publisher Site: https://hirurgiya.com.ua/index. php/journal/article/view/307

URL: https://hirurgiya.com.ua/index.php/journal/ article/view/307/20

15. Suleimanova VG, Shaprynskyi VO, Kryvetskyi VF, Nasr Zaki Nageeb, Hmelevska TA. Treatment of cervical necrotizing fasciitis, complicated by mediastinitis, on patient with hypoergic immune response. Hospital Surgery. Journal named by L.Ya. Kovalchuk. 2017;1:101-5. [in Ukrainian]. DOI: 10.11603/2414-4533.2017.1.6731 View at: Publisher Site: https://ojs.tdmu.edu.ua/index. php/surgery/article/view/6731

URL: https://ojs.tdmu.edu.ua/index.php/surgery/article/ view/6731/7236

\title{
КЛІНІКО-МІКРОБІОЛОГІЧНЕ ОБГРУНТУВАННЯ МІСЦЕВОГО ЗАСТОСУВАННЯ ГІДРОФІЛЬНО-ГІДРОФОБНОЇ КОМПОЗИЦІЇ НА ОСНОВІ НАНОКРЕМНЕЗЕМУ ПРИ ЛІКУВАННІ ХВОРИХ $З$ ОПІКАМИ
}

\author{
1Чорнопищук Р.М., ${ }^{1}$ Нагайчук B.I., ${ }^{2}$ Геращенко I.I, ${ }^{1}$ Назарчук О.А., ${ }^{3}$ Сидоренко С.А., \\ ${ }^{1}$ Чепляка О.М., ${ }^{4}$ Сидоренко Л.А.
}

${ }^{1}$ Вінницький національний медичний університет ім. М.І. Пирогова, Вінниия, Україна

${ }_{2}^{2}$ Інститут хімії поверхні ім. О.О. Чуйка НАН Украӥни, Київ, Украӥна

${ }^{3}$ Реабілітачійний иентр, Валенс, Швейиарія

${ }^{4}$ Державний університет медииини та фармації ім. М. Тестеміцану, Кишинів, Республіка Молдова

r.chornopyshchuk@gmail.com

Актуальність. Одним з перспективних методів лікування хворих з опіками розглядається місцеве використання сорбційних препаратів з антимікробними властивостями, яке потребує подальшого вивчення.

Ціль: експериментальне вивчення антимікробних властивостей та клінічна оцінка ефективності місцевого використання нового композиційного сорбційного препарату на основі нанорозмірного кремнезему при комплексному лікуванні хворих 3 опіками.

Матеріали та методи. До складу запропонованої сорбційної нанокомпозиції ввійшли високодисперсний кремнезем, поліметилксилоксан, декаметоксин, метронідазол.

Експериментальне дослідження передбачало вивчення антимікробних властивостей сорбційної композиції та антимікробних засобів, які входять до ії складу.

Дослідження «іn vivo» передбачало обстеження 42 пацієнтів з опіками ІІаб-ІІІ ступеня, площею 10-30\% поверхні тіла. Залежно від тактики місцевого лікування, пацієнти були поділені на 2 групи: у хворих основної групи $(\mathrm{n}=20)$ після ранньої некректомії, ксенодермопластики ранову поверхню обробляли розчином декаметоксину у поєднанні з однойменним сорбційним порошком. Лікування пацієнтів групи порівняння $(\mathrm{n}=22)$ було подібним, однак без використання сорбційних препаратів. Обстеження передбачало візуальний контроль ушкодженої ділянками у поєднанні $з$ мікробіологічним моніторингом ранового вмісту на 3, 7, 14 добу.

Результати. Отримані результати підтвердили достатню антимікробну активність досліджуваної сорбційної нанокомпозиції, за якою вона не поступається існуючим антисептичним засобам, щодо музейних та клінічних штамів мікроорганізмів і грибів.

Підтвердженням ефективності сорбційного препарату стали ознаки сприятливішого перебігу ранового процесу у хворих основної групи, що проявлялося швидшим очищенням ран, меншими проявами запальної реакції і значно коротшими термінами підготовки ран до аутодермопластики, забезпечуючи стабільний антимікробний ефект.

Висновки. Отримані результати переконливо вказують на ефективність багатокомпонентного препарату на основі нанокремнезему з антимікробними наповнювачами. Доцільним буде рекомендувати місцеве застосування подібного препарату у комплексній програмі лікування хворих з опіками.

Ключові слова: опіки, рановий процес, інфекція, антисептики, сорбенти. 


\title{
КЛИНИКО-МИКРОБИОЛОГИЧЕСКОЕ ОБОСНОВАНИЕ МЕСТНОГО ПРИМЕНЕНИЯ ГИДРОФИЛЬНО-ГИДРОФОБНОЙ КОМПОЗИЦИИ НА ОСНОВЕ НАНОКРЕМНЕЗЕМА ПРИ ЛЕЧЕНИИ БОЛЬНЫХ С ОЖОГАМИ
}

\author{
'Чернопищук Р.Н., ${ }^{1}$ Нагайчук В.И., ${ }^{2}$ Геращенко И.И, ${ }^{1}$ Назарчук А.А., ${ }^{3}$ Сидоренко С.А., \\ 'Чепляка А.Н., ${ }^{4}$ Сидоренко Л.А.
}

${ }^{1}$ Винниикий национальный медицинский университет им. Н.И. Пирогова, Винница, Украина ${ }^{2}$ Институт химии поверхности им. А.А. Чуйко НАН Украины, Киев, Украина

${ }^{3}$ Реабилитационный цеентр, Валенс, Швейцария

${ }^{4}$ Государственный университет медицины и фармащии им. Н. Тестемицану, Кишинёв, Республика Молдова

$$
\text { r.chornopyshchuk@gmail.com }
$$

Актуальность. Одним из перспективных методов лечения больных с ожогами считается местное использование сорбционных препаратов с антимикробными свойствами, которое требует дальнейшего изучения.

Цель: экспериментальное изучение антимикробных свойств и клиническая оценка эффективности местного применения нового композиционного сорбционного препарата на основе наноразмерного кремнезема при комплексном лечении больных с ожогами.

Материалы и методы. В состав предлагаемой сорбционной нанокомпозиции вошли высокодисперсный кремнезем, полиметилксилоксан, декаметоксин, метронидазол.

Экспериментальное исследование предусматривало изучение антимикробных свойств сорбционной композиции и антимикробных средств, которые входят в ее состав.

Исследование «in vivo» предусматривало обследования 42 пациентов с ожогами IIaб-III степени, площадью 10-30\% поверхности тела. В зависимости от тактики местного лечения пациенты были разделены на 2 группы: у больных основной группы (n=20) после ранней некрэктомии, ксенодермопластики раневую поверхность обрабатывали раствором декаметоксина в сочетании с одноименным сорбционным порошком. Лечение пациентов группы сравнения ( $\mathrm{n}=22)$ было подобным, однако без использования сорбционных препаратов. Обследование предусматривало визуальный контроль поврежденных участков в сочетании с микробиологическим мониторингом раневого содержимого на 3, 7, 14 сутки.

Результаты. Полученные результаты подтвердили достаточную антимикробную активность исследуемой сорбционной нанокомпозиции, согласно которым она не уступает существующим антисептическим средствам.

Подтверждением эффективности сорбционного препарата стали признаки благоприятного течения раневого процесса у больных основной группы, что проявлялось более быстрой очисткой ран, меньшими проявлениями воспалительной реакции, обеспечивая стабильный антимикробный эффект.

Выводы. Полученные результаты убедительно указывают на эффективность многокомпонентного препарата на основе нанокремнезема с антимикробными наполнителями. Целесообразным будет рекомендовать местное применение подобного препарата в комплексной программе лечения больных с ожогами.

Ключевые слова: ожоги, раневой процесс, инфекция, антисептики, сорбенты. 